\title{
The role of glucose kinase in carbohydrate utilization and extracellular polysaccharide production in Xanthomonas campestris pathovar campestris
}

\author{
Guang-Tao Lu, Zheng-Jiu Yang, Fang-Yin Peng, Yi-Ning Tan, \\ Yong-Qin Tang, Jia-Xun Feng, Dong-Jie Tang, Yong-Qiang He \\ and Ji-Liang Tang
}

Correspondence

Ji-Liang Tang

jltang@gxu.edu.cn

Received 11 June 2007

Revised 29 August 2007

Accepted 31 August 2007
Guangxi Key Laboratory of Subtropical Bioresources Conservation and Utilization, The Key Laboratory of Ministry of Education for Microbial and Plant Genetic Engineering, and College of Life Science and Technology, Guangxi University, 100 Daxue Road, Nanning, Guangxi 530004, China

\begin{abstract}
The genome of the Xanthomonas campestris pathovar campestris (XCC) strain 8004 encodes three uncharacterized proteins, XC1166, XC1223 and XC1976, annotated as glucose kinase (Glk) by bioinformatic studies. Here we have investigated the biochemical characteristics and physiological roles of these proteins with particular reference to the synthesis of extracellular polysaccharide (EPS). XC1166, XC1223 and XC1976 were overexpressed as fusion proteins with a $\mathrm{His}_{6}$ affinity tag and purified by nickel affinity chromatography. The standard Glk activity assay revealed that all three proteins possessed apparent Glk activity, with XC1976-His 6 being the most active; the specific activity values were $1.16 \times 10^{6} \mathrm{U} \mathrm{mg}^{-1}$ for $\mathrm{XC1166-His_{6 }}$, $4.36 \times 10^{7} \mathrm{U} \mathrm{mg}^{-1}$ for $\mathrm{XC1}_{1223-\mathrm{His}_{6}}$ and $2.63 \times 10^{8} \mathrm{U} \mathrm{mg}^{-1}$ for XC1976-His 6 . TLC analysis showed, however, that only $\mathrm{XC1976-His_{6 }}$ could phosphorylate glucose. Insertional mutants of XC1166, XC1223 and XC1976 were generated using the suicide plasmid pK18mob. Although mutant strains with insertions in XC1166 or XC1223 had Glk activity similar to that of the wild-type strain, the XC1976 mutant had only about $6 \%$ of the wild-type activity. Mutation in $X C 1976$ had complex effects on EPS production. In media containing arabinose, glucose, galactose, sucrose or maltose, the XC1976 mutant produced about $40-75 \%$ of the wild-type level of EPS, whereas in medium containing fructose, the mutant showed a $30 \%$ increase in EPS production compared to the wild-type strain. The XC1976 mutant also showed attenuated virulence on the host plant Chinese radish (Raphanus sativus). The results indicate that XC1976 has the most significant role for the parameters tested.
\end{abstract}

\section{INTRODUCTION}

The phytopathogenic bacterium Xanthomonas campestris pathovar campestris (hereafter Xcc), a strictly aerobic member of the family Xanthomonadaceae, is the causal agent of black rot disease of cruciferous crops worldwide (Onsando, 1992; Swings \& Civerolo, 1993). This bacterium produces extracellular polysaccharide (EPS) and extracellular enzymes (including amylase, endoglucanase, polygalacturonate lyase and protease), which are collectively essential for pathogenesis (Dow \& Daniels, 1994). EPS, also called xanthan gum, is an important industrial biopolymer which is used in a great variety of food and industrial applications as a viscosifying, thickening, stabilizing and suspending agent (Kennedy \& Bradshaw, 1984).

Abbreviations: EPS, extracellular polysaccharide; Glk, glucose kinase; $X_{C C}$, Xanthomonas campestris pathovar campestris.
Carbohydrate metabolism in $X c c$ has been investigated in some detail, as it is central to both EPS production and the mechanism of bacterial colonization. Xcc metabolizes sugars through a central metabolic network similar to that described for Pseudomonas aeruginosa (Temple et al., 1998). Glucose and sucrose have been shown to be the best carbon sources for EPS production (García-Ochoa et al., 2000). Two distinct pathways are employed to mobilize extracellular glucose for EPS production and energy generation. In the first pathway, glucose is transported directly into the cell by a permease and undergoes an intracellular phosphorylation catalysed by glucose kinase (EC 2.7.1.2, hereafter Glk) to yield glucose 6-phosphate (Lessie \& Phibbs, 1984; Letisse et al., 2001). Glucose 6-phosphate is then converted to gluconate by glucose-6-phosphate 1-dehydrogenase. Extracellular glucose can also be catabolized by an oxidative periplasmic 
pathway in which glucose is oxidized to gluconate via a periplasmic $\mathrm{NAD}(\mathrm{P})^{+}$-independent glucose dehydrogenase (Whitfield et al., 1982). This enzyme uses pyrroloquinoline quinone (PQQ) as cofactor (Duine \& Jongejan, 1989). Gluconate is transported into the cell by an active transport system involving gluconate permease. Gluconate from the two pathways is converted to 6-phosphogluconate and may be further metabolized via the Entner-Doudoroff pathway to yield glyceraldehyde 3-phosphate and pyruvate (Zagallo \& Wang, 1967). Some of these products may be recycled via gluconeogenesis for glucose phosphate production (Banerjee et al., 1987), while the remainder is oxidized via the tricarboxylic acid (TCA) cycle.

Glk has been predicted to be important for EPS production in Xcc (Letisse et al., 2001, 2002). The enzyme is responsible for phosphorylation of glucose using ATP as a donor to give glucose 6-phosphate and ADP. Although the eukaryotic Glks, such as yeast hexokinase B, Arabidopsis thaliana hexokinases and human hexokinase IV (HK4 or GCK, EC 2.7.1.1), are well characterized (Catanzano et al., 1997; Moore et al., 2003; Wilson, 2003), little is known about their bacterial and archaeal counterparts. A survey of the genome sequence data of two Xcc strains has revealed three genes predicted to encode Glk enzymes: XCC2137, XCC2886 and XCC2943 in strain ATCC 33913 (da Silva et al., 2002), and XC1166, XC1223 and XC1976 in strain 8004 (Qian et al., 2005). However, these genes and their protein products have not been experimentally investigated. Here we have examined the biochemical characteristics and physiological roles (particularly in EPS production) of the multiple Glk enzymes in Xcc strain 8004.

\section{METHODS}

Bacterial strains, plasmids and growth conditions. The bacterial strains and plasmids used in this study are listed in Table 1. Escherichia coli strains were grown in LB medium (Miller, 1972) at $37{ }^{\circ} \mathrm{C}$. Xcc strains were grown at $28{ }^{\circ} \mathrm{C}$ in NYG medium (per litre: $5 \mathrm{~g}$ peptone, 3 g yeast extract and 20 g glycerol; Daniels et al., 1984b) or the modified minimal medium MMX [per litre: $2.0 \mathrm{~g}\left(\mathrm{NH}_{4}\right)_{2} \mathrm{SO}_{4}$, $4.0 \mathrm{~g} \mathrm{~K}_{2} \mathrm{HPO}_{4}, 6.0 \mathrm{~g} \mathrm{KH}_{2} \mathrm{PO}_{4}, 0.2 \mathrm{~g} \mathrm{MgSO}_{4} \cdot 7 \mathrm{H}_{2} \mathrm{O}$, $1.0 \mathrm{~g}$ citric acid, $5.0 \mathrm{~g}$ sugar; Daniels et al., 1984a]. Antibiotics were added at the following concentrations as required: kanamycin (Kan), $25 \mu \mathrm{g} \mathrm{ml}^{-1}$; rifampicin (Rif), $50 \mu \mathrm{g} \mathrm{ml}^{-1}$; ampicillin (Amp), $100 \mu \mathrm{g} \mathrm{ml}^{-1}$; spectinomycin (Spc), $50 \mu \mathrm{g} \mathrm{ml}^{-1}$ and tetracycline (Tet), $5 \mu \mathrm{g} \mathrm{ml}^{-1}$ for Xcc and $15 \mu \mathrm{g} \mathrm{ml}^{-1}$ for E. coli.

DNA manipulations. The methods described by Sambrook et al. (1989) were used for preparation of the plasmid and chromosomal DNAs, restriction digestion, DNA ligation, agarose gel electrophoresis and DNA transformation of E. coli. The conjugation between Xcc and E. coli strains was performed as described by Turner et al. (1984). The restriction endonucleases, T4 DNA ligase and Pfu polymerase were provided by Promega (Shanghai).

Construction of insertional mutants. Mutants of the ORFs XC1166, XC1223 and XC1976 were constructed using the method previously described by Lu et al. (2007). A 300-500 bp internal

Table 1. Bacterial strains and plasmids used in this work

\begin{tabular}{|c|c|c|}
\hline \multicolumn{3}{|l|}{ E. coli } \\
\hline JM109 & recA1, endA1, gyrA96, thi, supE44, relA1 $\Delta\left(\right.$ lac-proAB)/ $\mathrm{F}^{\prime}\left[\right.$ traD36, lacl ${ }^{\mathrm{q}}$, lacZ $\left.\Delta \mathrm{M} 15\right]$ & Yanisch-Perron et al. (1985) \\
\hline HB101 & recA 13 rps & Boyer \& Roulland-Dussoix (1969) \\
\hline \multicolumn{3}{|r|}{$\log$} \\
\hline 8004 & Wild-type, Rif ${ }^{\mathrm{r}}$ & Daniels et al. (1984b) \\
\hline 1166nk & As 8004 , but $\mathrm{XC1} 166:: \mathrm{pK} 18 m o b, \mathrm{Rif}^{\mathrm{r}}, \mathrm{Kan}^{\mathrm{r}}$ & This work \\
\hline $1223 \mathrm{nk}$ & As 8004 , but XC1223::pK18mob, $\operatorname{Rif}^{\mathrm{r}}, \mathrm{Kan}^{\mathrm{r}}$ & This work \\
\hline C1976nk & 1976nk harbouring pLATC1976, Rif $^{\mathrm{r}}, \mathrm{Kan}^{\mathrm{r}}, \mathrm{Tc}^{\mathrm{r}}$ & This work \\
\hline \multicolumn{3}{|l|}{ Plasmids } \\
\hline pLAFR3 & Broad-host-range cloning vector, $\mathrm{Tra}^{-}, \mathrm{Mob}^{+}, \mathrm{Tc}^{\mathrm{r}}$ IncP replicon & Staskawicz et al. (1987) \\
\hline pLAFR6 & A promoterless derivative of pLAFR $3, \mathrm{Tc}^{\mathrm{r}}$ & Huynh et al. (1989) \\
\hline pK1223 & pK18mob containing a $430 \mathrm{bp}$ internal fragment of $X C 1223, \mathrm{Kan}^{\mathrm{r}}$ & This work \\
\hline pLATC1976 & pLAFR3 containing a 1222 bp fragment including the XC1976 gene, $\mathrm{Tc}^{\mathrm{r}}$ & This work \\
\hline pQE-30 & $\begin{array}{l}\text { Expression vector, allow the production of fusion proteins containing N-terminal } \\
6 \times \text { His-tagged sequences. } \mathrm{Amp}^{\mathrm{r}}\end{array}$ & Qiagen \\
\hline pQE-30-1166 & pQE-30 containing a $1032 \mathrm{bp}$ fragment of XC1976 coding region & This work \\
\hline pQE-30-1223 & pQE-30 containing a $1014 \mathrm{bp}$ fragment of $X C 1976$ coding region & This work \\
\hline pQE-30-1976 & pQE-30 containing a $1005 \mathrm{bp}$ fragment of XC1976 coding region & This work \\
\hline
\end{tabular}


fragment of the target ORF was amplified by PCR using the corresponding primers (Table 2). The amplified DNA fragments were cloned into suicide plasmid pK18mob (Schäfer et al., 1994; Windgassen et al., 2000) in the same orientation as the lacZ promoter to guarantee the construction of non-polar mutants. The resulting recombinant plasmid was introduced from E. coli strain JM109 (Yanisch-Perron et al., 1985) into the Xcc wild-type strain 8004 by triparental conjugation using pRK2073 (Leong et al., 1982) as the helper plasmid. Mutants were confirmed by PCR using oligonucleotide P18conF, and the corresponding oligonucleotide located downstream of the target ORF, as primers (Table 2).

Complementation of the insertional mutants. For mutant complementation, a 1222 bp DNA fragment containing the XC1976 coding region and extending from $212 \mathrm{bp}$ upstream of the $5^{\prime}$ end to 2 bp downstream of the $3^{\prime}$ end of the ORF was amplified using the primers C1976F/R (Table 2), and the amplified DNA fragment was cloned into the plasmid pLAFR3 (Staskawicz et al., 1987) to generate the recombinant plasmid pLATC1976 (Table 1). The recombinant plasmid was transferred into the XC1976 mutant by triparental conjugation, resulting in strain C1976nk (Table 1).

RT-PCR analysis. To analyse transcriptional expression levels, total RNA was isolated using Trizol reagent (Promega) and treated with RNase-free DNase (Promega). RT-PCR analysis was carried out with total RNA and specific primers for XC1166 (O1166F/R), XC1223 $(\mathrm{O} 1223 \mathrm{~F} / \mathrm{R})$ and XC1976 (O1976F/R) (Table 2). One microgram of total RNA was used for each reaction in a $20 \mu \mathrm{l}$ volume, and $4 \mu \mathrm{l}$ of the reaction mixture was subjected to PCR amplification. The PCR products were analysed by electrophoresis on $1.5 \%(\mathrm{w} / \mathrm{v})$ agarose gels, and verified by DNA sequencing.

Overproduction and purification of protein. For overproduction of XC1166, XC1223 and XC1976, their corresponding ORFs were amplified using the primers O1166F/R, O1223F/R and O1976F/R (Table 2), respectively. After being confirmed by sequencing, the amplified DNA fragments were cloned into the expression vector pQE-30 (Qiagen) (Table 1) to generate recombinant plasmids pQE30-1166, pQE-30-1223 and pQE-30-1976 (Table 1), respectively. In these plasmids, XC1166, XC1223 or XC1976 is fused N-terminally inframe to the $\mathrm{His}_{6}$-tag coding region of the plasmid $\mathrm{pQE}-30$. The recombinant plasmids obtained were transformed into E. coli strain JM109, resulting in strains JM109/pQE-30-1166, JM109/pQE-301223 and JM109/pQE-30-1976 (Table 1), respectively. For fused proteins XC1166-His 6 , XC1223-His 6 and XC1976-His X $_{6}$ overproduction and purification, strains were grown to $\mathrm{OD}_{600} 0.6$, and then induced by addition of $1.0 \mathrm{mM}$ IPTG. The cultures were grown for a further $4 \mathrm{~h}$. The fused proteins were purified by Ni-NTA resin (Qiagen). The proteins were checked by $12 \%$ SDS-PAGE and used for enzymic assay.

Cell-free extract preparation. $X c c$ strains were grown in NYG medium supplemented with $2 \%$ glucose or fructose for $20 \mathrm{~h}$. Cells were harvested and washed twice in sterile water by centrifugation. The cells were then resuspended in $2 \mathrm{ml} 20 \mathrm{mM}$ potassium phosphate ( $\mathrm{pH} 7.5$ ) containing $1 \mathrm{mM}$ dithiothreitol and $0.1 \mathrm{mM}$ EDTA and disrupted by sonication. The sonicates were centrifuged and the supernatant fractions were used in the enzyme assay.

GIk assay. Glk activity from purified proteins or cell-free extracts was measured by an enzyme-linked assay based on the $\mathrm{NADP}^{+} / \mathrm{NADPH}$ ratio (Gonzali et al., 2001). Ten microlitres of the protein sample was transferred to a $5 \mathrm{ml}$ tube containing $2 \mathrm{ml}$ reaction buffer $[100 \mathrm{mM}$ Tris/ $\mathrm{HCl}$ (pH 7.4), $100 \mathrm{mM} \mathrm{KCl}, 7.5 \mathrm{mM} \mathrm{MgSO}_{4}, 5 \mathrm{mM}$ ATP, $0.5 \mathrm{mM} \mathrm{NADP}^{+}, 5 \mathrm{mM} \beta$-mercaptoethanol, $100 \mathrm{mM}$ glucose and $0.2 \mathrm{U}$ glucose-6-phosphate dehydrogenase $\mathrm{ml}^{-1}$ ]. After incubation for 10 min at $37{ }^{\circ} \mathrm{C}, A_{340}$ was measured. A unit of enzyme activity was taken as $1 \mathrm{nmol}$ NADPH formed $\mathrm{min}^{-1}$ (mg protein $)^{-1}$; the protein concentration in the samples was determined by the BCA protein assay kit (Pierce Biotechnology). For characterizing kinetic parameters of the purified proteins, the reaction mixture including $1.0 \mu \mathrm{g}$ purified Glk, and a range of D-glucose or ATP concentrations $(0.05-20 \mathrm{mM})$, was used under standard assay conditions. Michaelis-Menten kinetic parameters were evaluated by the double reciprocal-plot method.

The phosphorylation of different sugars by the purified proteins was monitored by TLC, as described by Meyer et al. (1997). Purified proteins were incubated with $50 \mathrm{mM}$ sugar in $50 \mathrm{mM}$ Tris/ $\mathrm{HCl}$ ( $\mathrm{pH}$ 7.4) containing $10 \mathrm{mM} \mathrm{MgCl}_{2}$ and $50 \mathrm{mM}$ ATP. The assay

Table 2. Primers used in this study

Underlined sequences indicate restriction sites for BamHI and HindIII.

\begin{tabular}{|c|c|c|}
\hline Primer & Nucleotide sequence $\left(5^{\prime}-3^{\prime}\right)$ & Amplified segment or primer location \\
\hline $1976 \mathrm{kF}$ & ACAGTTAAGCTTTGCTCCTTCCAAGCCGGTGCTGGT & 484 bp DNA fragment spans nt 6-489 of the XC1976 ORF sequence \\
\hline $1976 \mathrm{kR}$ & ACAGTTGGATCCAAAACAGCGGCCGTTGCGGATGAT & \\
\hline $\mathrm{C} 1976 \mathrm{~F}$ & ACAGTTAAGCTTACTCATCGCTGCTCTCCC & 1222 bp DNA fragment spans 212 bp upstream and 2 bp down- \\
\hline C1976R & ACAGTTGGATCCTATGAACGCTTGTTCGTG & stream of the XC1976 ORF sequence \\
\hline $1166 \mathrm{~F}$ & ACAGTTAAGCTTCATGCTCGATCGGCAGAT & 357 bp DNA fragment spans nt $278-634$ of the XC1166 ORF sequence \\
\hline $1166 \mathrm{R}$ & 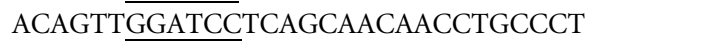 & \\
\hline $1223 \mathrm{~F}$ & ACAGTTGGATCCTTGCACCTGGTCAACGAT & $430 \mathrm{bp}$ DNA fragment spans nt $343-772$ of the $X C 1223$ ORF sequence \\
\hline $1223 \mathrm{R}$ & ACAGTTAAGCTTAGAACGTCTGCAGCGCCT & \\
\hline P18conF & GCCGATTCATTAATGCAGCTGGCAC & Located in $\mathrm{pK} 18 m o b$ \\
\hline O1976F & ACAGTTAAGCTTTCGCTGCTCTCCCGGCAA & $1005 \mathrm{bp}$ of the $X C 1976 \mathrm{ORF}$ \\
\hline O1976R & ACAGTT $\overline{\text { GGATCCATGACTGCTCCTTCCAAG }}$ & \\
\hline O1166F & ACAGTTAAGCTTCGACACCTCGGTGTGGTG & $1032 \mathrm{bp}$ of the XC1166 ORF \\
\hline O1166R & ACAGTTGGATCCGTGGCTGCAACCTCGCAC & \\
\hline O1223F & ACAGTTGGATCCGTGAGCGCAAGCAGCCCA & 1014 bp of the $X C 1223$ ORF \\
\hline O1223R & ACAGTTAAGCTTGCGGCCGTGCTGCAGGAA & \\
\hline
\end{tabular}


volume was $100 \mu \mathrm{l}$ containing $10 \mu \mathrm{g}$ protein. After $2 \mathrm{~h}$ incubation, an $8 \mu \mathrm{l}$ sample was spotted onto the silica-coated TLC plate (Qingdao Haiyang Chemical) and the plate was then developed with butanolethanol-water $(5: 3: 2$, by vol.) for $3 \mathrm{~h}$. After drying the TLC plate, the sugar-containing spots were visualized by dipping the plate in methanol containing $2 \%$ concentrated $\mathrm{H}_{2} \mathrm{SO}_{4}$, followed by drying and charring for $8 \mathrm{~min}$ at $150{ }^{\circ} \mathrm{C}$.

EPS assay. To estimate EPS production, strains were cultured in $100 \mathrm{ml} \mathrm{NYG} \mathrm{liquid} \mathrm{medium} \mathrm{containing} 2 \%(\mathrm{w} / \mathrm{v})$ various sugars at $28{ }^{\circ} \mathrm{C}$ with shaking at 200 r.p.m. for 3 days. EPS was precipitated from the culture supernatant with ethanol, dried and weighed as described by Tang et al. (1991).

Virulence assay. The virulence of $X c c$ to Chinese radish (Raphanus sativus) was tested by the leaf-clipping method (Dow et al., 2003). Leaves were cut with scissors dipped in the bacterial suspensions of an $\mathrm{OD}_{600}$ of 0.1 . Lesion length was measured 10 days after inoculation, and data were analysed by $t$ test. The growth of bacteria in radish leaf tissue was determined as previously described (Lu et al., 2007).

\section{RESULTS}

\section{Enzyme characteristics of the predicted Glks XC1166, XC1223 and XC1976}

The three hypothetical proteins annotated as Glk from Xcc strain 8004 are the 344 aa protein XC1166 (YP_242256), the 338 aa protein XC1223 (YP_242312) and the 335 aa protein XC1976 (YP_243059). Sequence comparison (Vector NTI suite 9.0) revealed only limited amino acid sequence similarity among these proteins, which displayed only $24.0 \%$ identical residues (Fig. 1). This suggests that the three proteins have distinct functions. The three predicted Glk proteins in Xcc possess the same Pfam domain (PF02685) and they are the only proteins with such a domain in the $X c c$ proteome. Wider similarity searches revealed that these proteins also share limited identical residues with characterized Glks from other microbial sources: XC1976 has 38.4 and $19.3 \%$ identity, respectively, to the E. coli enzyme (accession no. AAC75447) and the Streptomyces coelicolor A3(2) enzyme (accession no. CAA46727). XC1166 and XC1223 share 31 and $27.9 \%$ identity, respectively, with the E. coli enzyme, and 16.3 and $14.5 \%$ identity with the $S$. coelicolor enzyme.

To explore the biochemical characteristics of the products of these genes, XC1166, XC1223 and XC1976 were overexpressed with $\mathrm{His}_{6}$-tags in E. coli strain JM109, as outlined in Methods. Separation of crude cell lysates on SDS-PAGE showed intense protein bands migrating at the expected molecular mass of $35.5 \mathrm{kDa}$ (Fig. 2). Fusion proteins with a $\mathrm{His}_{6}$-tag were purified using a Ni-NTA column, to obtain preparations apparently free from contaminating proteins (Fig. 2).

The standard assay for measuring Glk activity, in which the phosphorylation of glucose is coupled to the formation of NADPH by glucose-6-phosphate dehydrogenase (Gonzali et al., 2001), was used to test enzyme properties and kinetic constants of the fusion proteins (see Methods). All three

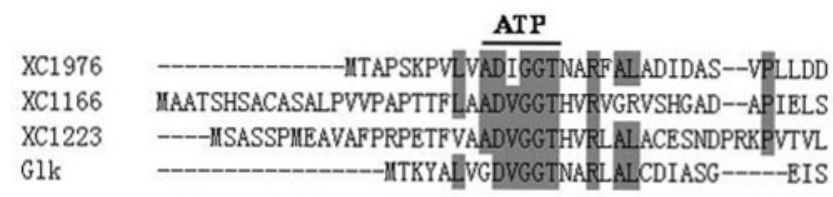

XC1976

$\mathrm{XC1166}$

XC1223

Glk

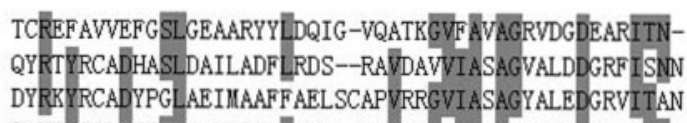
QAKTYSGLDYPSLEAVIRVYLEEHK-VEVKD GCIAI ACPITGDWVANTN-
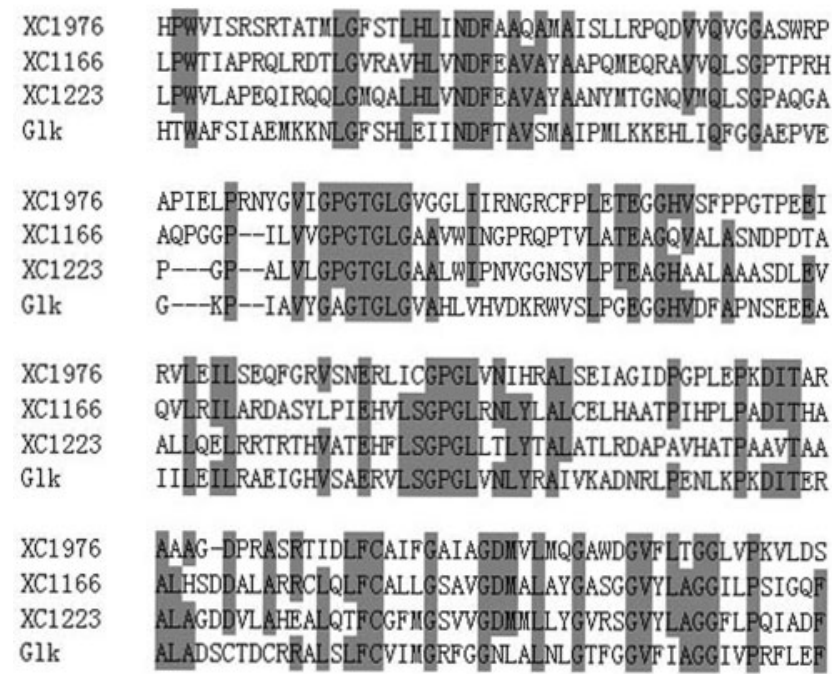

XC1976

$\mathrm{XC1166}$

$\mathrm{XC1223}$

Glk

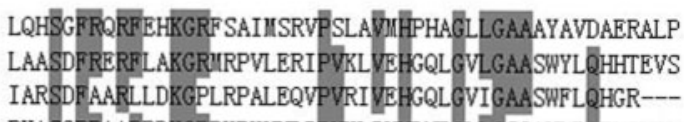
FRASGFRAAFEDKGRFKEYVHDIPVYLIVHDNPGLLGSGAHLRQTLGHIL

$\begin{array}{ll}\text { XC1976 } & \text { GEQR } \\ \text { XC1166 } & --- \\ \text { XC1223 } & --- \\ \text { Glk } & ---\end{array}$

Fig. 1. Comparison of the predicted amino acid sequences of XC1976, XC1166 and XC1223 with that of the E. coli Glk (AAC75447). Residues that are identical in at least three sequences are shown with a grey background. The black line above the sequence (ATP) indicates the putative ATP-binding site (Meyer et al., 1997).

fusion proteins exhibited Glk activity in the presence of ATP by this method; however, no significant enzymic activity was observed without ATP (data not shown). The specific activity values were determined to be $1.16 \times 10^{6} \mathrm{U}$ (mg protein) ${ }^{-1}$ for $\mathrm{XC1} 166-\mathrm{His}_{6}, 4.36 \times 10^{7} \mathrm{U} \mathrm{mg}^{-1}$ for $\mathrm{XC12}^{2}-\mathrm{His}_{6}$ and $2.63 \times 10^{8} \mathrm{U} \mathrm{mg}^{-1}$ for XC1976-His 6 . The apparent $K_{\mathrm{m}}$ values for glucose were $4.02 \mathrm{mM}$ for XC1166$\mathrm{His}_{6}, 4.20 \mathrm{mM}$ for XC1223-His ${ }_{6}$ and $2.52 \mathrm{mM}$ for XC1976$\mathrm{His}_{6}$, while the apparent $K_{\mathrm{m}}$ values for ATP were $2.50 \mathrm{mM}$ $\left(\mathrm{XC1}_{166-\mathrm{His}_{6}}\right), 1.85 \mathrm{mM}\left(\mathrm{XC1223}^{-\mathrm{His}_{6}}\right)$ and $1.25 \mathrm{mM}$

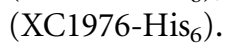

The enzymic activities of the purified proteins were further assessed by examination of glucose phosphorylation by 


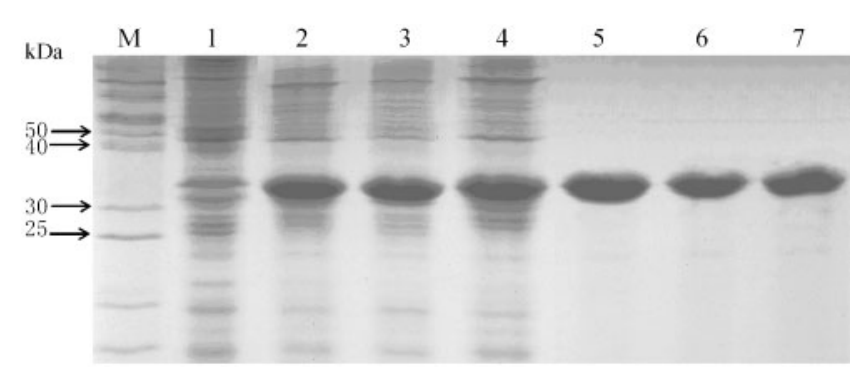

Fig. 2. SDS-PAGE analysis of the $\mathrm{His}_{6}$-tagged recombinant proteins XC1166, XC1223 and XC1976 of Xcc. Lanes: 1, crude extract of $E$. coli JM109; 2, crude extract of $E$. coli JM109/pQE30-1166 after induction with IPTG; 3, crude extract of $E$. coli JM109/pQE-30-1223 after induction with IPTG; 4, crude extract of E. coli JM109/pQE-30-1976 after induction with IPTG; 5, affinity-purified $\mathrm{His}_{6}-\mathrm{XC1166}$ protein; 6, affinity-purified $\mathrm{His}_{6}{ }^{-}$ XC1223 protein; 7, affinity-purified $\mathrm{His}_{6}-\mathrm{XC1976}$ protein; $\mathrm{M}$, molecular mass markers.

TLC (see Methods). Purified proteins were incubated with $50 \mathrm{mM}$ glucose and $50 \mathrm{mM}$ ATP for $2 \mathrm{~h}$ at $37^{\circ} \mathrm{C}$ before TLC separation of substrates and products. Although phosphorylation of glucose by XC1976-His ${ }_{6}$ could be observed by this method (Fig. 3), no phosphorylation of glucose by $\mathrm{XC1166}_{-} \mathrm{His}_{6}$ and $\mathrm{XC1223-His}_{6}$ was detected. To examine the sugar substrate specificity of XC1166, XC1223 and XC1976, these assays were repeated under the same conditions using a range of sugars, including arabinose, xylose, sorbitol (glucitol), mannose, mannitol, sorbose, fructose, galactose, rhamnose, sucrose and maltose. No phosphorylation of any of these sugars by XC1166$\mathrm{His}_{6}$, XC1223-His ${ }_{6}$ or XC1976-His ${ }_{6}$ could be detected (data not shown). Taken together, these results indicate that XC1976 is a Glk and not a hexokinase.

Analysis of the genome sequence of Xcc strain 8004 revealed that XC1976 is probably transcribed as the

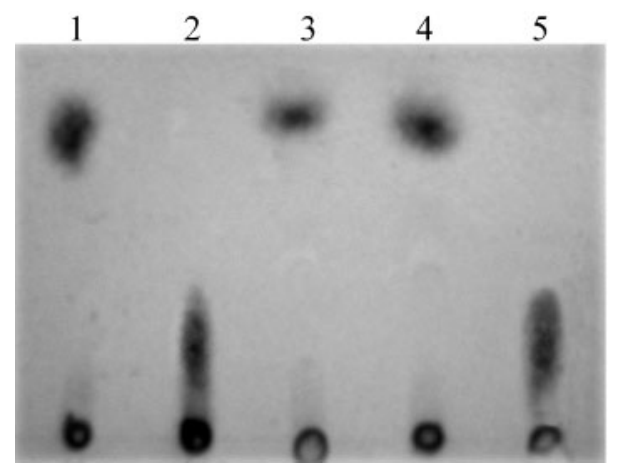

Fig. 3. Phosphorylation of glucose by the $\mathrm{His}_{6}$-tagged recombinant proteins XC1166, XC1223 and XC1976 revealed by TLC. An $8 \mu \mathrm{l}$ sample of each reaction mixture was spotted onto TLC plates. Lanes: 1, glucose standard; 2, glucose 6-phosphate standard; 3, $\mathrm{His}_{6}-\mathrm{XC1166}$; $\mathrm{His}_{6}-\mathrm{XC1} 223 ; 5, \mathrm{His}_{6}-\mathrm{XC1} 1976$.
XC1977-XC1976-XC1975 operon. XC1977 is annotated as a putative glucose-6-phosphate 1-dehydrogenase, whereas XC1975 is annotated as an orthologue of 6-phosphogluconolactonase. The linked genes XC1974 and XC1973 are predicted to encode 6-phosphogluconate dehydratase and 2-keto-3-deoxy-6-phosphogluconate aldolase, respectively. Therefore, the genes XC1977-XC1973 might encode five enzymes probably responsible for glucose catabolism by the Entner-Doudoroff pathway (Conway, 1992), suggesting a role for XC1976 in this pathway of glucose metabolism.

\section{XC1976 makes the major contribution to GIk activity in Xcc}

To demonstrate the physiological role of the three genes, non-polar mutants carrying insertional disruption within the ORF XC1166, XC1223 or XC1976 were constructed and named 1166nk, 1223nk and 1976nk, respectively (Table 1; see Methods). RT-PCR analysis showed that full-length transcripts for each gene are present in the wild-type strain but not in the corresponding mutant (Fig. 4).

The Glk activities in the wild-type and mutant strains were then measured. Cell extracts were prepared from cultures grown in NYG liquid medium containing $2 \%$ glucose or fructose. A level of activity was found in all the tested strains in the absence of ATP (Table 3); this might reflect the glucose dehydrogenase activity of Xcc. As summarized in Table 3, the Glk activities in the XC1166 and XC1223 mutants were not different from that in the wild-type strain 8004. However, the XC1976 mutant showed a substantial reduction in enzymic activity, whereby the level of ATPdependent activity was only $6 \%$ of the wild-type level. XC1976 was cloned as a $1222 \mathrm{bp}$ DNA fragment in plasmid pLAFR3 to give pLATC1976 (see Methods). Introduction of pLATC1976 into the XC1976 mutant resulted in a strain that expressed the XC1976 transcript (Fig. 4) and that had a level of Glk activity that was considerably elevated over that of the wild-type (Table 3). XC1976 is the central gene in the XC1977-XC1975 operon (see above) and is unlikely to have its own promoter. The lac promoter of the vector pLAFR3, which is active in Xcc (Soby \& Daniels, 1996), probably drives expression of XC1976 in pLATC1976. Consistent with this interpretation, when the $1222 \mathrm{bp}$ fragment was cloned into the promoterless vector pLAFR6 (Huynh et al., 1989), the resulting construct could not restore the Glk activity of the XC1976 mutant (data not shown). Overall, these results indicate that XC1976 makes the most significant contribution to the total Glk activity in Xcc, when the bacterium grows in NYG medium supplemented with glucose or fructose.

\section{XC1976 influences the utilization of glucose, sucrose and maltose}

To examine the effect of mutation in XC1166, XC1223 and XC1976 on the ability of Xcc to utilize various carbon sources, the growth of different bacterial strains was tested. 


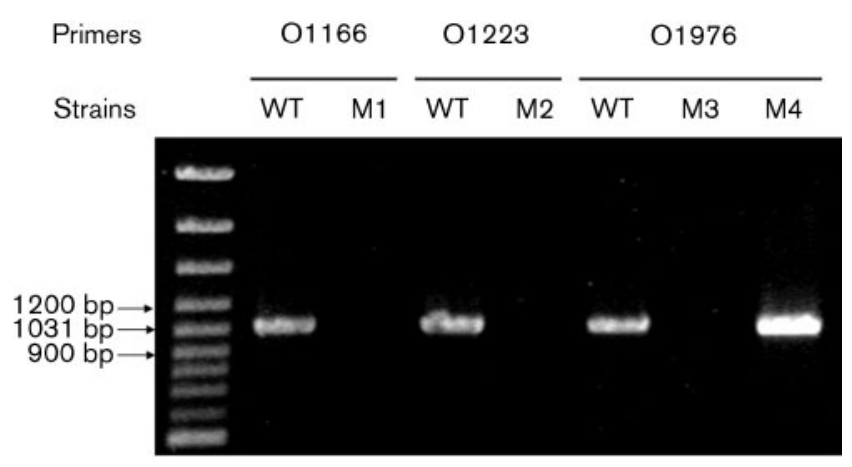

Fig. 4. RT-PCR analysis of the expression of $X C 1166, X C 1223$ and $X C 1976$. Total RNA from cells grown in NYG medium for $20 \mathrm{~h}$ was used as template for reverse transcription. WT, wild-type strain; M1, M2 and M3, mutant strains 1166nk, 1223nk and 1976nk, respectively; M4, the complemented mutant strain C1976nk.

Bacteria were grown on minimal medium MMX agar plates containing arabinose, xylose, glucose, sorbitol, mannose, mannitol, sorbose, fructose, galactose, rhamnose, sucrose or maltose as the sole carbon source. The growth of the XC1166 and XC1223 mutants was similar to that of the wild-type strain 8004 under all conditions tested (data not shown). However, the XC1976 mutant displayed smaller colonies than the wild-type strain on plates containing glucose, sucrose or maltose. Introduction of pLATC1976 (which carries the XC1976 gene) into the XC1976 mutant restored the wild-type phenotype (data not shown). When cultured in liquid medium, the XC1976 mutant grew with reduced growth rates compared to the wild-type. The doubling times in glucose were $7.1 \mathrm{~h}$ for the mutant and $4.4 \mathrm{~h}$ for the wild-type, in sucrose $5.9 \mathrm{~h}$ for the mutant and $4.6 \mathrm{~h}$ for the wild-type, and in maltose $6.8 \mathrm{~h}$ for the mutant and $4.7 \mathrm{~h}$ for the wild-type. However, when cultured in the nutrient-rich complex medium NYG containing glucose, sucrose or maltose, the XC1976 mutant grew in a similar fashion to the wild-type strain (data not shown). These results indicate that the Glk-defective mutant is still able to utilize glucose, sucrose or maltose, although to a more limited extent than the wild-type.

\section{XC1976 influences EPS production}

To evaluate the EPS production of these mutants, strains were grown on NYG agar plates supplied with a range of sugars. The XC1166 and XC1223 mutants showed the same colony size as the wild-type strain 8004 on all agar plates tested, indicating equivalent production of EPS. However, the XC1976 mutant displayed colonies that were smaller than the wild-type on plates containing arabinose, glucose, sorbitol, mannitol, galactose, sucrose or maltose, larger than the wild-type on plates containing fructose or sorbose, and the same as the wild-type on plates containing xylose, mannose or rhamnose. These findings suggest that the XC1976 gene might have complex effects on EPS production, promoting it in arabinose-, glucose-, sorbitol-, mannitol-, galactose-, sucrose- or maltose-containing medium, but inhibiting it in fructose- or sorbose-containing medium.

To quantitatively estimate the EPS production of the mutants, strains were grown in NYG liquid medium supplemented with $2 \%$ of various carbohydrates for 3 days, and EPS was extracted from the cultures (see Methods). As summarized in Table 4, the XC1976 mutant produced about 25-60\% less EPS than the wild-type strain 8004 when cultured in arabinose-, glucose-, galactose-, sucrose- or maltose-containing medium. In addition, the EPS yield of the complemented mutant strain showed no significant difference from that of the wild-type. Conversely, the XC1976 mutant produced more EPS than the wild-type when cultured in fructose-containing medium. The EPS yield of the mutant was increased about $30 \%$ compared to that of the wild-type strain, and reached $8.5 \mathrm{~g} \mathrm{l}^{-1}$, which is approaching the level of the wild-type strain cultured in glucose- or sucrose-containing medium. Surprisingly, complementation did not restore EPS production on fructose to wild-type level.

\section{Table 3. Glk activity in Xcc strains}

Strains were cultured in NYG liquid medium supplemented with glucose or fructose. Data presented are from a representative experiment and similar results were obtained in two other independent experiments. Data are mean \pm SD of triplicate measurements. Different letters in each data column indicate significant differences at $P=0.05$ ( $t$ test).

\begin{tabular}{|c|c|c|c|c|c|c|}
\hline \multirow[t]{2}{*}{ Strain } & \multicolumn{6}{|c|}{ Glk activity $\left[\mathrm{nmol} \mathrm{NADPH} \min ^{-1}(\mathrm{mg} \text { protein })^{-1}\right]$} \\
\hline & \multicolumn{3}{|c|}{ Glucose } & \multicolumn{3}{|c|}{ Fructose } \\
\hline 8004 (wild-type) & $21.8 \pm 4.3$ & $101.9 \pm 18.3$ & $80.1 \mathrm{a}$ & $20.1 \pm 5.2$ & $94.9 \pm 12$ & $74.8 \mathrm{a}$ \\
\hline 1976nk (XC1976 mutant) & $20.3 \pm 4.4$ & $24.9 \pm 5.2$ & $4.6 \mathrm{~b}$ & $16.8 \pm 4.3$ & $19.2 \pm 3.7$ & $2.4 \mathrm{~b}$ \\
\hline 1223nk (XC1223 mutant) & $21.5 \pm 5.5$ & $91.4 \pm 12.2$ & $77.6 \mathrm{a}$ & $19.2 \pm 6.2$ & $91.3 \pm 15$ & $72.1 \mathrm{a}$ \\
\hline
\end{tabular}


Table 4. EPS production in Xcc strains

Strains were cultured in NYG liquid medium supplemented with various carbon sources. Data presented are from a representative experiment and similar results were obtained in two other independent experiments. Data are mean \pm SD of triplicate measurements. Different letters in each data column indicate significant differences at $P=0.05$ ( $t$ test).

\begin{tabular}{|c|c|c|c|c|c|c|c|c|c|c|c|c|}
\hline \multirow[t]{2}{*}{ Strain } & \multicolumn{12}{|c|}{ EPS yield $\left(\mathrm{g} \mathrm{l}^{-1}\right)$} \\
\hline & Arabinose & Xylose & Glucose & Sorbitol & Mannose & Mannitol & Sorbose & Fructose & Galactose & Rhamnose & Sucrose & Maltose \\
\hline $\begin{array}{l}8004 \\
\quad \text { (wild-type) }\end{array}$ & $3.41 \pm 0.25 \mathrm{a}$ & $2.52 \pm 0.17 \mathrm{a}$ & $9.35 \pm 0.25 a$ & $1.15 \pm 0.13 a$ & $6.23 \pm 0.28 a$ & $1.02 \pm 0.08 \mathrm{a}$ & $1.23 \pm 0.23 \mathrm{a}$ & $6.26 \pm 0.24 a$ & $7.11 \pm 0.32 \mathrm{a}$ & $4.32 \pm 0.19 a$ & $9.12 \pm 0.28 \mathrm{a}$ & $9.10 \pm 0.28 \mathrm{a}$ \\
\hline $\begin{array}{l}\text { 1976nk (XC1976 } \\
\text { mutant) }\end{array}$ & $2.16 \pm 0.47 b$ & $2.34 \pm 0.22 \mathrm{a}$ & $4.03 \pm 0.35 b$ & $1.17 \pm 0.22 \mathrm{a}$ & $6.57 \pm 0.34 a$ & $1.14 \pm 0.16 a$ & $1.78 \pm 0.53 a$ & $8.75 \pm 0.36 b$ & $5.33 \pm 0.36 a$ & $4.25 \pm 0.37 \mathrm{a}$ & $4.55 \pm 0.31 b$ & $3.28 \pm 0.52 b$ \\
\hline $\begin{array}{l}\text { C1976nk } \\
\text { (complemented } \\
\text { mutant) }\end{array}$ & $3.43 \pm 0.17 \mathrm{a}$ & $2.48 \pm 0.15 a$ & $9.65 \pm 0.58 a$ & $1.08 \pm 0.16 \mathrm{a}$ & $6.68 \pm 0.45 a$ & $1.18 \pm 0.11 \mathrm{a}$ & $1.25 \pm 0.26 \mathrm{a}$ & $8.56 \pm 0.27 b$ & $6.95 \pm 0.24 a$ & $4.35 \pm 0.31 \mathrm{a}$ & $8.75 \pm 0.21 \mathrm{a}$ & $8.62 \pm 0.28 \mathrm{a}$ \\
\hline $\begin{array}{l}1166 \mathrm{nk}(\mathrm{XC} 1166 \\
\text { mutant) }\end{array}$ & $3.22 \pm 0.28 \mathrm{a}$ & $2.55 \pm 0.24 a$ & $9.44 \pm 0.33 a$ & $1.13 \pm 0.24 a$ & $6.75 \pm 0.53 a$ & $1.05 \pm 0.21 \mathrm{a}$ & $1.31 \pm 0.34 \mathrm{a}$ & $6.35 \pm 0.42 a$ & $7.15 \pm 0.35 a$ & $4.27 \pm 0.41 \mathrm{a}$ & $9.09 \pm 0.19 a$ & $9.15 \pm 0.25 \mathrm{a}$ \\
\hline $\begin{array}{l}\text { 1223nk (XC1223 } \\
\text { mutant) }\end{array}$ & $3.17 \pm 0.37 \mathrm{a}$ & $2.43 \pm 0.08 \mathrm{a}$ & $9.32 \pm 0.23 a$ & $1.05 \pm 0.14 a$ & $6.51 \pm 0.44 a$ & $1.13 \pm 0.19 a$ & $127 \pm 0.42 a$ & $6.52 \pm 0.15 a$ & $7.13 \pm 0.24 a$ & $4.18 \pm 0.36 a$ & $9.23 \pm 0.26 a$ & $9.06 \pm 0.33 a$ \\
\hline
\end{tabular}

\section{XC1976 is required for full virulence and in planta growth}

The virulence assay for the $X c c$ strains was performed on Chinese radish by the leaf-clipping method and measurement of the length of lesions (Dow et al., 2003). Ten days after inoculation, the XC1976 mutant showed a mean lesion length of $5.48 \mathrm{~mm}$ on the leaves, while the wild-type strain, as well as the mutants of XC1166 and XC1223, showed a mean lesion length of about $12 \mathrm{~mm}$. As analysed by $t$ test, the mean lesion length caused by the XC1976 mutant was significantly shorter than that caused by the wild-type strain $(P=0.01)$. In contrast, when the XC1976 mutant was transformed with plasmid pLATC1976, the virulence of the mutant could be restored to wild-type; the lesion lengths caused by the complemented strain and the wild-type strain were not significantly different $(P=0.05)$ (Fig. 5b). These results show that Glk activity is required for the full virulence of $X c c$.

To determine whether mutation in XC1976 results in a decrease in the proliferation of $X c c$ in the host, the numbers of the mutant bacterial cells in infected radish leaves were calculated. The number of the mutant bacterial cells was approximately three- to eightfold lower than that of the wild-type strain 1 day post-inoculation and after (Fig. 5c). The growth of the mutant in planta could be completely restored by pLATC1976. These results show that Glk activity affects the growth of $X c c$ as well as the production of symptoms in planta.

\section{DISCUSSION}

In this work, we have demonstrated that XC1976 in Xcc is the most active and makes the largest contribution to the total Glk activity, and that the protein influences EPS production in a complex fashion and is required for full virulence towards plants.
The insertional mutants of XC1166 and XC1223 still had Glk activity similar to that of the wild-type (Table 3 ), and no phosphorylation of glucose by either XC1166- $\mathrm{His}_{6}$ or $\mathrm{XC1223-His}_{6}$ could be observed on silica-coated TLC plates. We thus suppose that XC1166 and XC1223 do not serve as a Glk in Xcc, despite the close similarity of their amino acid sequences to those of other microbial Glks (Fig. 1) and the Glk activity of the purified proteins as measured in the linked assay (Table 3 ). These proteins could not phosphorylate any of a range of other sugars tested. Analysis of the deduced protein sequence using the SMART algorithm (http://smart.embl-heidelberg.de) showed differences in domain structure among XC1166, XC1223 and XC1976. All three proteins contain a Glk domain (PF02685); however, XC1166 and XC1223 have in addition a Rok domain [residues $24-218$ of XC1166 $\left(8.70 \mathrm{e}^{-3}\right)$ and residues $20-215$ of $\left.\mathrm{XC1223}\left(1.10 \mathrm{e}^{-2}\right)\right]$. The family of proteins with a Rok domain consists of repressors, ORFs with unidentified functions, and sugar kinases (Titgemeyer et al., 1994). This difference in domain composition suggests that XC1166 and XC1223 fulfil other cellular functions, which remain obscure and require more work before they can be understood.

In $X c c$, glucose uptake relies on two discrete systems: the intracellular phosphorylation pathway and the periplasmic oxidative pathway (Whitfield et al., 1982; Lessie \& Phibbs, 1984). Extracellular glucose entering cellular metabolism via the intracellular phosphorylation pathway will lead to the production of glucose 6-phosphate. Some of the glucose 6-phosphate will enter the pathways for polysaccharide production via phosphoglucomutase, and the remainder will enter the central metabolic network via glucose-6-phosphate dehydrogenase. Metabolic flux modelling predicts that if all external glucose enters the cytosol via the periplasmic pathway, no EPS will be synthesized. Conversely, if most glucose enters metabolism via intracellular phosphorylation, less EPS will be produced 


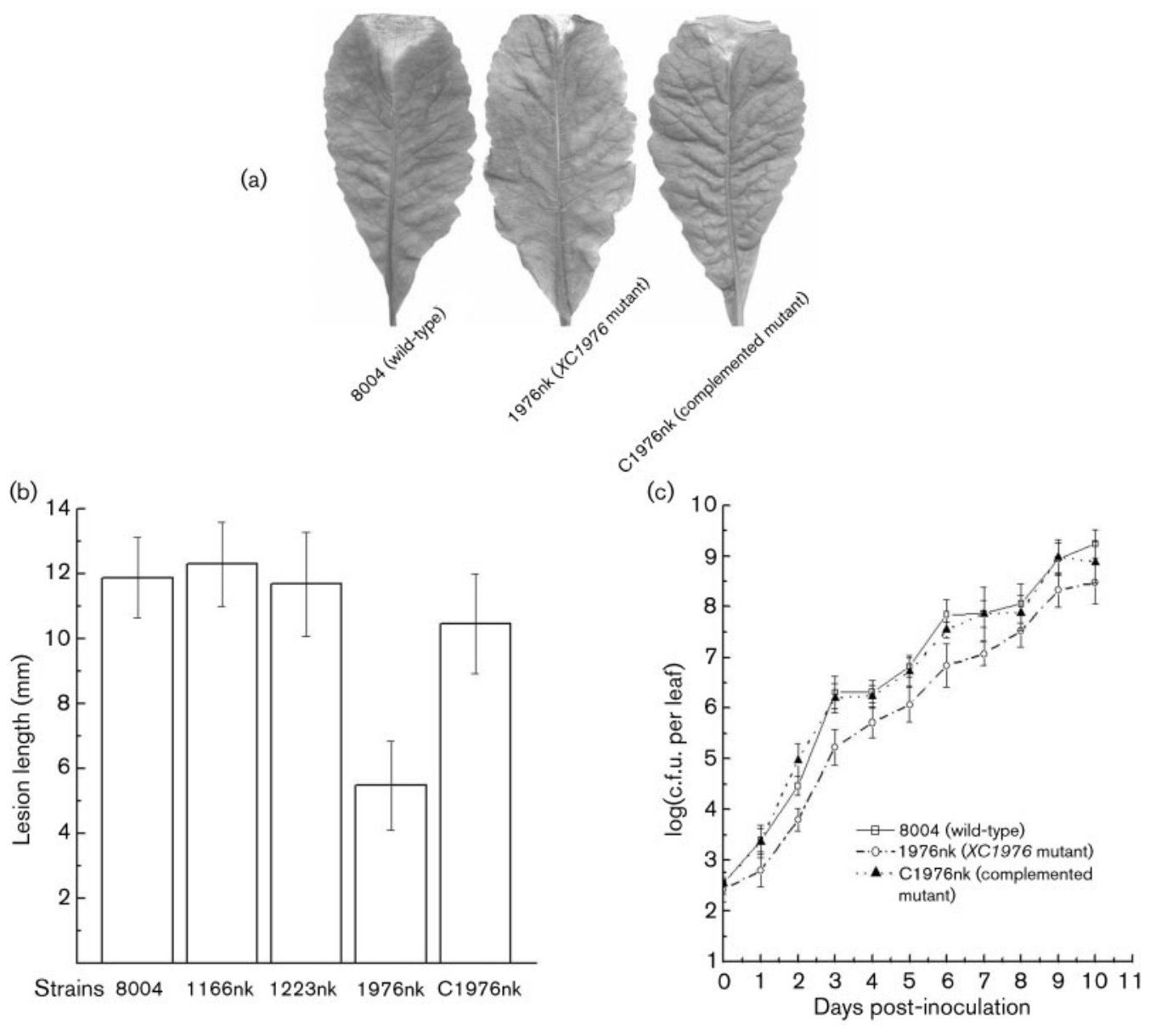

Fig. 5. XC1974 is required for full virulence of $X_{C C}$ to Chinese radish. (a) Symptom production on leaves 10 days after inoculation by clipping with the XC1976 mutant, the wild-type and the complemented mutant. (b) Mean lesion lengths caused by different $X_{C c}$ strains. 1166nk and 1223nk have full virulence, and 1976nk has attenuated virulence; as analysed by the $t$ test, the mean lesion length caused by 1976 nk was significantly shorter $(P=0.01)$ than that caused by the wild-type. Values given are the mean $\pm S D$ from 15 measurements. (c) Bacterial populations of the XC1976 mutant, the wild-type and the complemented mutant strain in host plant leaves. Inoculated leaves for each strain were taken daily and homogenized in sterile water. The homogenates were diluted and then plated on agar plates. Bacterial c.f.u. were counted after incubation for 3 days. Data are the mean $\pm S D$ from three replicates.

because the availability of biochemical energy is limited (Letisse et al., 2002). Here we have shown that inactivation of XC1976 greatly reduced the Glk activity in Xcc. One consequence of this may be to impede glucose mobilization via the permease/phosphorylation pathway and lead to a decrease in the cellular level of precursors for EPS synthesis, with a resulting reduction in EPS yield.

The XC1976 mutant also produced less EPS than the wildtype when cultured in medium supplemented with arabinose, galactose, sucrose or maltose as carbon source. The sucrose-utilization system in Xcc has recently been described in some detail and is clearly different from that of other bacteria (Blanvillain et al., 2007; Kim et al., 2004; Reid \& Abratt, 2005). In Xcc, extracellular sucrose is transported through the outer membrane via a TonBdependent receptor (SuxA), and through the inner membrane via a sugar transporter (SuxC). The intracellular sucrose is then hydrolysed by sucrose hydrolase (SUH) to yield glucose and fructose. The impeding of glucose phosphorylation through inactivation of XC1976 may thus lead to less sucrose utilization via EPS synthesis. Little is known about the pathways for utilization of arabinose, galactose or maltose in $\mathrm{Xcc}$, although conversion of maltose (a disaccharide of glucose) to glucose seems likely.

Interestingly, the XC1976 mutant produced more EPS than the wild-type in fructose-containing medium. When plasmid pLATC1976, which resulted from the cloning of XC1976 in plasmid pLAFR3, was introduced into the XC1976 mutant, the resulting complemented strain 
displayed about $50 \%$ higher Glk activity than the wild-type strain when cultured in NYG medium containing 2\% fructose, but still produced more EPS than the wild-type (Table 3). To confirm the effect of XC1976 mutation, three other isolates of the XC1976 mutant were selected at random to test in fructose-containing medium; all produced more EPS than the wild-type (data not shown).

A similar phenomenon has been observed in S. coelicolor, in which both inactivation and overexpression of Glk result in a loss of carbon catabolite repression (CCR) of glycerol kinase and agarase (Kwakman \& Postma, 1994). Glk has been implicated in the mechanism of CCR in several bacteria from the genera Streptomyces, Staphylococcus and Bacillus (Angell et al., 1992, 1994; Kwakman \& Postma, 1994; Wagner et al., 1995; Spath et al., 1997). CCR ensures that micro-organisms adjust their metabolic activities to utilize specific carbon sources in their environment (Brückner \& Titgemeyer, 2002). A phosphoenolpyruvatedependent phosphotransferase system (PTS) identified to be responsible for fructose transportation and phosphorylation in other bacteria (Prior \& Kornberg, 1988; Geerse et al., 1989; Wu et al., 1990) has been demonstrated in Xcc, and a pathway for fructose catabolism has also been proposed (de Crécy-Lagard et al., 1991a, b, 1995). However, although some details of fructose metabolism are understood, little is known about either the regulation of fructose utilization or CCR in Xcc. Further investigations are needed to fully understand the contribution of XC1976 to such regulatory processes.

Mutation of XC1976 also attenuates the virulence of Xcc to Chinese radish and leads to a reduction of growth in this host plant. It is possible that these effects result from an impairment of EPS synthesis by bacteria in planta. EPS plays an important role during bacterial infection. It can enhance the susceptibility of host plants by suppressing defence responses such as callose formation (Yun et al., 2006), and contribute to biofilm formation (Dow et al., 2003) and bacterial resistance against host defences. It may also serve to mask the bacterium to prevent recognition by the host and to enable colonization of host tissues (Alvarez, 2000). An alternative, but not mutually exclusive, view is simply that the reduction in ability to utilize available carbohydrates in the plant reduces bacterial growth with consequences for the aggressiveness of the pathogen. Consistent with this, it has recently been demonstrated that sucrose utilization is required for full pathogenicity in Xcc (Blanvillain et al., 2007). Previously, we have shown that an Xcc ppsA mutant, which is unable to utilize C4-dicarboxylates as carbon source, has limited growth in plant hosts and reduced virulence compared to the wild-type (Tang et al., 2005). Collectively, our findings suggest that the utilization of plant carbohydrates as well as C4-dicarboxylates is required for the full virulence of $X c c$. These carbon sources may be available in different amounts at different stages of infection, as bacteria initially utilize components of the xylem fluid before mobilizing carbon sources by enzymic degradation of host polymers as black rot disease progresses.

\section{ACKNOWLEDGEMENTS}

We are grateful to J. Maxwell Dow for critically reading the manuscript. This work was supported by The National Science Foundation of China (30470944) and the '863' Program of the Ministry of Science and Technology of China (20060102Z1097).

\section{REFERENCES}

Alvarez, A. M. (2000). Black rot of crucifers. In Mechanisms of Resistance to Plant Diseases, pp. 21-52. Edited by A. J. Slusarenko, R. S. S. Fraser \& L. C. van Loon. Dordrecht: Kluwer Academic Publications.

Angell, S., Lewis, C. G. \& Bibb, M. J. (1992). The glucokinase gene of Streptomyces coelicolor A3(2): its nucleotide sequence, transcriptional analysis and role in glucose repression. Mol Microbiol 6, 2833-2844.

Angell, S., Lewis, C. G., Buttner, M. J. \& Bibb, M. J. (1994). Glucose repression in Streptomyces coelicolor A3(2): a likely regulatory role for glucose kinase. Mol Gen Genet 244, 135-143.

Banerjee, P. C., Darzins, A. \& Maitra, P. K. (1987). Gluconogenic mutations in Pseudomonas aeruginosa: genetic linkage between fructose-bisphosphate aldolase and phosphoglycerate kinase. J Gen Microbiol 133, 1099-1107.

Blanvillain, S., Meyer, D., Boulanger, A., Lautier, M., Guynet, C., Denance, N., Vasse, J., Lauber, E. \& Arlat, M. (2007). Plant carbohydrate scavenging through TonB-dependent receptors: a feature shared by phytopathogenic and aquatic bacteria. PLoS ONE 2, e224.

Boyer, H. W. \& Roulland-Dussoix, D. (1969). A complementation analysis of the restriction and modification of DNA in Escherichia coli. J Mol Biol 41, 459-472.

Brückner, R. \& Titgemeyer, F. (2002). Carbon catabolite repression in bacteria: choice of the carbon source and autoregulatory limitation of sugar utilization. FEMS Microbiol Lett 209, 141-148.

Catanzano, F., Gambuti, A., Graziano, G. \& Barone, G. (1997). Interaction with $\mathrm{D}$-glucose and thermal denaturation of yeast hexokinase B: a DSC study. J Biochem (Tokyo) 121, 568-577.

Conway, T. (1992). The Entner-Doudoroff pathway: history, physiology, and molecular biology. FEMS Microbiol Rev 9, 1-27.

da Silva, A. C., Ferro, J. A., Reinach, F. C., Farah, C. S., Furlan, L. R., Quaggio, R. B., Monteiro-Vitorello, C. B., Van Sluys, M. A., Almeida, N. F. \& other authors (2002). Comparison of the genomes of two Xanthomonas pathogens with differing host specificities. Nature 417, 459-463.

Daniels, M. J., Barber, C. E., Turner, P. C., Cleary, W. G. \& Sawczyc, M. K. (1984a). Isolation of mutants of Xanthomonas campestris pathovar campestris showing altered pathogenicity. J Gen Microbiol 130, 2447-2455.

Daniels, M. J., Barber, C. E., Turner, P. C., Sawczyc, M. K., Byrde, R. J. \& Fielding, A. H. (1984b). Cloning of genes involved in pathogenicity of Xanthomonas campestris pv. campestris using the broad host range cosmid pLAFR1. EMBO J 3, 3323-3328.

de Crécy-Lagard, V., Bouvet, O. M., Lejeune, P. \& Danchin, A. (1991a). Fructose catabolism in Xanthomonas campestris pv. campestris: sequence of the PTS operon, characterization of the fructosespecific enzymes. J Biol Chem 266, 18154-18161.

de Crécy-Lagard, V., Lejeune, P., Bouvet, O. M. \& Danchin, A. (1991b). Identification of two fructose transport and phosphorylation pathways in Xanthomonas campestris pv. campestris. Mol Gen Genet 227, 465-472.

de Crécy-Lagard, V., Binet, M. \& Danchin, A. (1995). Fructose phosphotransferase system of Xanthomonas campestris pv. campestris: characterization of the fruB gene. Microbiology 141, 2253-2260. 
Dow, J. M. \& Daniels, M. J. (1994). Pathogenicity determinants and global regulation of pathogenicity in Xanthomonas campestris pv. campestris. In Molecular and Cellular Mechanisms in Bacterial Pathogenesis of Plants and Animals, pp. 29-41. Edited by J. L. Dangl. Berlin: Springer.

Dow, J. M., Crossman, L., Findlay, K., He, Y.-O., Feng, J.-X. \& Tang, J.-L. (2003). Biofilm dispersal in Xanthomonas campestris is controlled by cell-cell signaling and is required for full virulence to plants. Proc Natl Acad Sci U S A 100, 10995-11000.

Duine, J. A. \& Jongejan, J. A. (1989). Quinoproteins, enzymes with pyrrolo-quinoline quinone as cofactor. Annu Rev Biochem 58, 403-426.

Garcia-Ochoa, F., Santos, V. E., Casas, J. A. \& Gómez, E. (2000). Xanthan gum: production, recovery, and properties. Biotechnol Adv 18, 549-579.

Geerse, R. H., Izzo, F. \& Postma, P. W. (1989). The PEP : fructose phosphotransferase system in Salmonella typhimurium: FPr combines enzyme IIIFru and pseudo-HPr activities. Mol Gen Genet 216, 517-525.

Gonzali, S., Pistelli, L., De Bellis, L. \& Alpi, A. (2001). Characterization of two Arabidopsis thaliana fructokinases. Plant Sci 160, 1107-1114.

Huynh, T. V., Dahlbeck, D. \& Staskawicz, B. J. (1989). Bacterial blight of soybean: regulation of a pathogen gene determining host cultivar specificity. Science 245, 1374-1377.

Kennedy, J. F. \& Bradshaw, I. J. (1984). Production, properties and applications of xanthan. Prog Ind Microbiol 19, 319-371.

Kim, H. S., Park, H. J., Heu, S. \& Jung, J. (2004). Molecular and functional characterization of a unique sucrose hydrolase from Xanthomonas axonopodis pv. glycines. J Bacteriol 186, 411-418.

Kwakman, J. H. \& Postma, P. W. (1994). Glucose kinase has a regulatory role in carbon catabolite repression in Streptomyces coelicolor. J Bacteriol 176, 2694-2698.

Leong, S. A., Ditta, G. S. \& Helinski, D. R. (1982). Heme biosynthesis in Rhizobium: identification of a cloned gene coding for deltaaminolevulinic acid synthetase from Rhizobium meliloti. J Biol Chem 257, 8724-8730.

Lessie, T. G. \& Phibbs, P. V. (1984). Alternative pathways of carbohydrate utilization in Pseudomonas. Annu Rev Microbiol 38, 359-387.

Letisse, F., Chevallereau, P., Simon, J. L. \& Lindley, N. D. (2001). Kinetic analysis of growth and xanthan gum production with Xanthomonas campestris on sucrose, using sequentially consumed nitrogen sources. Appl Microbiol Biotechnol 55, 417-422.

Letisse, F., Chevallereau, P., Simon, J. L. \& Lindley, N. (2002). The influence of metabolic network structures and energy requirements on xanthan gum yields. J Biotechnol 99, 307-317.

Lu, G.-T., Ma, Z.-F., Hu, J.-R., Tang, D.-J., He, Y.-Q., Feng, J.-X. \& Tang, J.-L. (2007). A novel locus involved in extracellular polysaccharide production and virulence of Xanthomonas campestris pathovar campestris. Microbiology 153, 737-746.

Meyer, D., Schneider-Fresenius, C., Horlacher, R., Peist, R. \& Boos, W. (1997). Molecular characterization of glucokinase from Escherichia coli K-12. J Bacteriol 179, 1298-1306.

Miller, J. H. (1972). Experiments in Molecular Genetics. Cold Spring Harbor, NY: Cold Spring Harbor Laboratory.

Moore, B., Zhou, Z., Rolland, F., Hell, O., Cheng, W. H., Liu, Y. X., Hwang, I., Jones, T. \& Sheen, J. (2003). Role of the Arabidopsis glucose sensor HXK1 in nutrient, light and hormonal signaling. Science 300, 332-336.

Onsando, J. M. (1992). Black rot of crucifers. In Plant Diseases of International Importance II: Diseases of Vegetable and Oil Seed Crops, pp. 243-252. Edited by H. S. Chaube, J. Kumar, A. N. Mukhopadhyay \& U. S. Singh. Englewood Cliffs, NJ: Prentice Hall.
Prior, T. I. \& Kornberg, H. L. (1988). Nucleotide sequence of fruA, the gene specifying enzyme IIfru of the phosphoenolpyruvate-dependent sugar phosphotransferase system in Escherichia coli K12. J Gen Microbiol 134, 2757-2768.

Qian, W., Jia, Y., Ren, S.-X., He, Y.-Q., Feng, J.-X., Lu, L.-F., Sun, Q., Ying, G., Tang, D.-J. \& other authors (2005). Comparative and functional genomic analyses of the pathogenicity of phytopathogen Xanthomonas campestris pv. campestris. Genome Res 15, 757-767.

Reid, S. J. \& Abratt, V. R. (2005). Sucrose utilisation in bacteria: genetic organisation and regulation. Appl Microbiol Biotechnol 67, 312-321.

Sambrook, J., Fritsch, E. F. \& Maniatis, T. (1989). Molecular Cloning: a Laboratory Manual, 2nd edn. Cold Spring Harbor, NY: Cold Spring Harbor Laboratory.

Schäfer, A., Tauch, A., Jäger, W., Kalinowski, J., Thierbach, G. \& Pühler, A. (1994). Small mobilizable multi-purpose cloning vectors derived from the Escherichia coli plasmids pK18 and pK19: selection of defined deletions in the chromosome of Corynebacterium glutamicum. Gene 145, 69-73.

Soby, S. D. \& Daniels, M. J. (1996). Catabolite-repressor-like protein regulates the expression of a gene under the control of the Escherichia coli lac promoter in the plant pathogen Xanthomonas campestris pv. campestris. Appl Microbiol Biotechnol 46, 559-561.

Spath, C., Kraus, A. \& Hillen, W. (1997). Contribution of glucose kinase to glucose repression of xylose utilization in Bacillus megaterium. J Bacteriol 179, 7603-7605.

Staskawicz, B., Dahlbeck, D., Keen, N. \& Napoli, C. (1987). Molecular characterization of cloned avirulence genes from race 0 and race 1 of Pseudomonas syringae pv. glycinea. J Bacteriol 169, 5789-5794.

Swings, J. G. \& Civerolo, E. L. (1993). Xanthomonas. London: Chapman \& Hall.

Tang, J.-L., Liu, Y.-N., Barber, C. E., Dow, J. M., Wootton, J. C. \& Daniels, M. J. (1991). Genetic and molecular analysis of a cluster of $r p f$ genes involved in positive regulation of synthesis of extracellular enzymes and polysaccharide in Xanthomonas campestris pathovar campestris. Mol Gen Genet 226, 409-417.

Tang, D. J., He, Y. Q., Feng, J. X., He, B. R., Jiang, B. L., Lu, G. T., Chen, B. \& Tang, J. L. (2005). Xanthomonas campestris pv. campestris possesses a single gluconeogenic pathway that is required for virulence. J Bacteriol 187, 6231-6237.

Temple, L. M., Sage, A. E., Schweizer, H. P. \& Phibbs, P. V. (1998). Carbohydrate catabolism in Pseudomonas aeruginosa. In Pseudomonas, pp. 35-72. Edited by T. C. Montie. New York \& London: Plenum Press.

Titgemeyer, F., Reizer, J., Reizer, A. \& Saier, M. H., Jr (1994). Evolutionary relationships between sugar kinases and transcriptional repressors in bacteria. Microbiology 140, 2349-2354.

Turner, P., Barber, C. \& Daniels, M. J. (1984). Behavior of the transposons Tn5 and Tn7 in Xanthomonas campestris pv. campestris. Mol Gen Genet 195, 101-107.

Wagner, E., Marcandier, S., Egeter, O., Deutscher, J., Götz, F. \& Brückner, R. (1995). Glucose kinase-dependent catabolite repression in Staphylococcus xylosus. J Bacteriol 177, 6144-6152.

Whitfield, C., Sutherland, I. W. \& Cripps, R. E. (1982). Glucose metabolism in Xanthomonas campestris. J Gen Microbiol 128, 981-985.

Wilson, J. E. (2003). Isoenzymes of mammalian hexokinase: structure, subcellular localization and metabolic function. J Exp Biol 206, 2049-2057.

Windgassen, M., Urban, A. \& Jaeger, K. E. (2000). Rapid gene inactivation in Pseudomonas aeruginosa. FEMS Microbiol Lett 193, 201-205.

Wu, L. F., Tomich, J. M. \& Saier, M. H., Jr (1990). Structure and evolution of a multidomain multiphosphoryl transfer protein: nucleotide sequence of the $f r u B(\mathrm{HI})$ gene in Rhodobacter capsulatus 
and comparisons with homologous genes from other organisms. J Mol Biol 213, 687-703.

Yanisch-Perron, C., Vieira, J. \& Messing, J. (1985). Improved M13 phage cloning vectors and host strains: nucleotide sequences of the M13mp18 and pUC19 vectors. Gene 33, 103-119.

Yun, M. H., Torres, P. S., El Oirdi, M., Rigano, L. A., GonzalezLamothe, R., Marano, M. R., Castagnaro, A. P., Dankert, M. A.,
Bouarab, K. \& Vojnov, A. A. (2006). Xanthan induces plant susceptibility by suppressing callose deposition. Plant Physiol 141, 178-187.

Zagallo, A. C. \& Wang, C. H. (1967). Comparative glucose catabolism of Xanthomonas species. J Bacteriol 93, 970-975.

Edited by: M. F. Hynes 